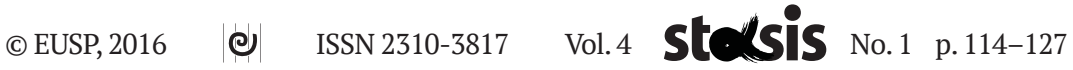
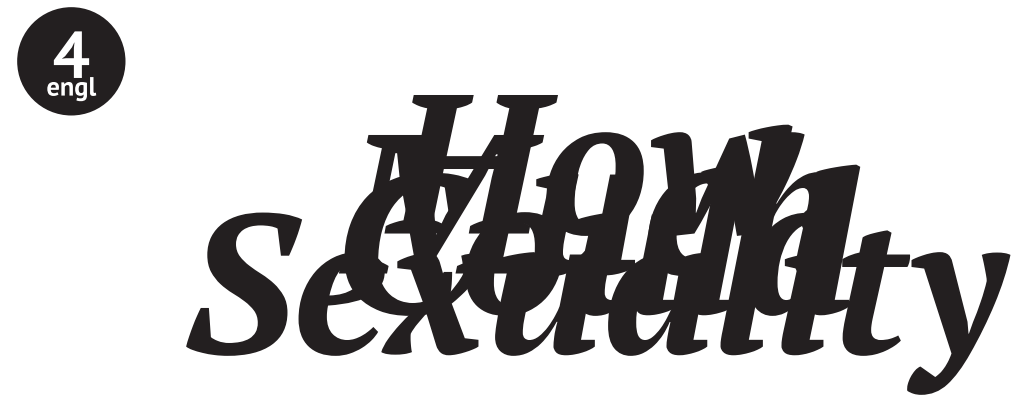

\author{
Keti Chukhrov
}

Russian State University for Humanities, Moscow

\title{
How Much Could Sexuality Cost
}

\begin{abstract}
Sexuality is not possible without phantasm, phantasm is not possible without the imaginaries maintained by private property. Private property resides in surplus economy.

Surplus economy is libidinal. The question would then be: how much could sexuality cost? Or does sexuality vanish if the economy stops to be libidinal?
\end{abstract}

\section{Keywords}

consciousness, libidinal, sexuality 


\section{How Much Could Sexuality Cost}

When we question what sexuality is we also have to ask whether it is a universal category or whether it is biased-by economic, social, and class constellations of certain historical periods or social formations. Another question would be whether sexuality and sex are identical notions and whether one can substitute another.

These questions arise as long as sexuality is not reducible to any statistics of sexual intercourse, but is rather conditioned by various modes of surplus: in desire, in economic production, in language. That sexuality is libidinally biased and hence inscribed into a broader context of libidinal economy is obvious, so the question follows: in the case of production functioning without surplus value, can it be regarded as non-libidinal (e.g., the distributive economy of socialism), and if so, would this conjecture make it possible to dispense with sexuality?

The argument against such an assumption is that the Soviet socialist economy was to a considerable extent also capitalist, only on behalf of a state, so that it always contained the libidinal dimension which was merely suppressed. Another argument is that sexuality, desire, pleasure, the unconscious, are universal components in the construction of a subject in general. If they thereby happen to be suppressed they manifest themselves obliquely in some other, not necessarily sexual, experience or its physical implementation.

I would consider both arguments as doubtful. Distributive economywhether functioning well or badly-was grounded on use value. This is why the commodity in Soviet social space didn't fit into the phantasmatic image of a desire. Apart from being phantasmatically imagined, desire has to be materially embodied: it needs to be produced, it needs to become and manifest itself as a product, and consequently as a commodity in to which the phantasms and desires can be inscribed. This implies that the economy and production should fit into the material realization of such a phantasm. Sexuality for Foucault was a clinical category, for Freud a psychic one, for Lacan it was linguistic. But in all these cases one point is overlooked. Sexuality being the kernel of desire cannot but construct itself via implementing its imaginaries materially-which makes it inevitably concomitant to the economy and to the types of production at hand.

For Lacan or Deleuze, social infrastructure is permeated by sexuality, the unconscious is dispersed within it. Nevertheless, missing in their research is the possibility of the evacuation of all libidinal parameters as the result of the sublation of libidinal economy. In other words, if the type of economic production is not supplying the possibility to generate imaginaries of sexuality and the material sources to implement them, the question would be whether sexuality is being acted out at all? (Neither Lacan nor Deleuze endeavored to research such a society). 


\section{Keti Chukhrov}

From this standpoint, the second argument regarding the all-encompassing universality of sexuality might be discarded, then making the presupposition that the latency of sexuality in Soviet society (the absence of any libidinally biased images in media, social space, art, the censorship for issues of sexuality as against the narratives of love) was not just the outcome of bureaucratic restrictions, but stemmed from the specific social and economic modes of production. ${ }^{1}$

\section{II}

Andrey Platonov's short pamphlet "The Anti-Sexus" is written as an advertisement for a device providing coital service, produced in France and mainly distributed in capitalist countries. This machine of sexual satisfaction's ultimate biopolitical function varies, from regulating sexual life in marriage to the evacuation of sexuality from relationships in favor of friendship and enthusiastic labor and production, up to the overall extinction of prostitution, or even so far as to make marriage obsolete to increase workers' productivity in factories. In other words, it is meant to dispense with the libidinal striving of humanity, as well as with the troubles of the unconscious altogether by supplying a universal device of quick sexual satisfaction. Although the text is written on behalf of a Western company, it implicitly refers to the biopolitics of sexuality in early Soviet society with a plan to drastically reframe the ethical, ideological, psychic, and physiological map not only of a concrete Soviet society, but of human existence in general.

However, what the Anti-Sexus device aims to remove from life and communication is not so much sex, but rather sexuality: libidinality, desire, the drive. It is not removing the function of sexual intercourse-the nominal implementation of the sexual act is preserved in the application of this device. What is obliterated is precisely the yearning, the libidinal, the surplus element, and the elusive "something." Genital satisfaction as against sexuality does not necessarily reside in desire-it is implemented as an immediate bio-physiological need. Applying the Anti-Sexus device for such stimulation enables people to get rid of the troublesome realm of desire. Tearing libidinal drives away from the realm of physiological necessities helps to shift focus on to social activity by directly satisfying genital needs.

This mischievous and ambivalent pamphlet could be read in two registers-as grotesque irony and as a straightforward message, implicitly presupposing that the society from which sexuality is evicted already ex-

1 Interestingly, the Soviet artist Boris Mikhailov (2007), who has been working with issues of gender and body since the early 1960s, said he could only photograph a naked Soviet body endowed with any sexuality at the end of the 1980s. 
ists and in which there are certain reasons to regard sexuality, libidinal desire and the unconscious as the obsolete sides of social life.

Another question arising from this text is whether this Anti-Sexus machine is a masturbation device or not. It nominally functions as a tool of self-satisfaction. However, what hampers this device from being a masturbation tool is its compulsory and open representation in public space. It deals with publicly observed sexual satisfaction as a necessity, then losing its libidinal aureole and becoming a mere social function.

\section{III}

If we look at the works of Lev Vygotsky, Valentin Voloshinov, ${ }^{2}$ the short manifestos by Andrey Platonov and at the later research of Evald Ilyenkov, we can see they are all vocabularies of social emancipation grounded on the notion of consciousness rather than the unconscious, consequently marking a watershed between psychoanalysis and Marxist thought. These authors' treatment of the notion of consciousness implies a dispute between the impact of the unconscious and the psychic altogether. In his well-known and very much disputed work Freudianism, Voloshinov (1976) juxtaposes Psychoanalysis and Marxism, according to him consciousness is only a social and never an individual consciousness. In Ilyenkov's "Dialectics of Abstract and Concrete," consciousness can only take the form of social consciousness (1991: 275-94). It is the screen of generality where the general is what speaks with the voice of all and any. Consciousness in this case stops to be the capacity of individual introspection, to be the function of transcendental reflection.

In his Analysis of Consciousness in Works by Marx, Mamardashvili writes that Marx's approach to economic phenomena does not infer psychic operations:

(Marx) constructed his research so that already in the point of departure he had to deal with the systems, functioning and realized via consciousness. These were for him the social and economic systems. Hence it became possible to consider consciousness as the function, as the attribute of the social system, deducing its contents and form from the intersections and differentiations in the system and not from the simple reflection of the object in the subject's perception (Mamardashvili, 1972, own translation).

2 Some texts by Valentin Voloshinov referring to the issues of psychoanalysis have been ascribed to Mikhail Bakhtin and have been published under his name (Bakhtin 2000). 


\section{Keti Chukhrov}

But if all social data is reflected by consciousness then contact with external reality is not conditioned by the unconscious. The general criticism of psychoanalysis instigated by Vygotsky and Voloshinov posited that the unconscious has its role, but cannot be substantialized. To claim that the psyche and sexuality are independent realms impenetrable by consciousness was an exaggeration on the part of Voloshinov in Freudianism. But the motivation for such a stance was not so much in disputing the existence of the unconscious and its psychoanalytical treatment, but rather an ethical demand asserting that in general the unconscious and psychoanalysis cannot exert a social function. The unconscious was understood as a realm unable to attain the dimension of the general, and to truly imply social (common) interest. The unconscious elements were inferred just as something non-conscious, or not-yet-conscious, hence they didn't have to be regarded as an autonomous sphere of the psyche, since treating them within a framework of the psyche and by means of the psychoanalytical method would distance them from objective reality. If this is so, body and physiology should not necessarily be considered within the prism of psychics, but rather remain in the context of the materialistic realm of biology. Biology and physiology are transcribed more easily and directly into the social (and hence economically biased terms) than into the psychic ones, subject to psychoanalytical treatment. Thus, for all the above mentioned authors the psychoanalytical treatment of the unconscious, sexuality and psyche was considered to be the forced libidinization of all forms of life, its subjection to the pleasure principle.

In his short text "But a Human has One Soul," Platonov writes:

The primary function in the life of a man was not thought, not consciousness, but the sexual drive-the striving to reproduce life, the first clash with death, with the wish of immortality and eternity.

We live at the time when sex is devoured by thought. The dark and beautiful passion is evicted from life due to consciousness. Philosophy of the proletariat discovered consciousness and it supports the struggle of consciousness with the ancient, but still living beast. In this struggle resides the sense of the revolution nurturing the spirit of humanity.

Bourgeoisie gave birth to the proletariat, $\operatorname{sex}\left(п о \pi^{3}\right)$-generated consciousness. Sexuality is the soul of the bourgeoisie, consciousness is the soul of the proletariat. The bourgeoisie and sex completed their task in life-they should be abolished (Platonov 1988: 531-33, own translation).

Interestingly, when Vygotsky and Luria wrote in 1925 a rather complimentary foreword to Freud's "Beyond Pleasure Principle” (1990 sexuality.

It is more appropriate to translate пол (sex) as biological sex, rather than 
[1925]: 29-37), their main argument in Freud's defense was that in his description of the realm beyond pleasure, Freud managed to return to pure biology and evade psychics. Psychics for the Soviet Marxists was some kind of euphemism for spiritualism. What they approved of in this work by Freud is how psychics is exceeded by broader biological procedures and is thus considered to be part of a bigger realm of biological phenomena. Vygotsky claims that Freud's todestrieb (death drive) overcomes the libidinal principle of drive, unraveling in it a materialistic, biological angle (1990: 29-37).

The reason biological forces are preferable to psychic ones in the works of both Vygotsky and Voloshinov is due to the "conservative" tendencies of biology. The fact that biological phenomena are able to be directly affected by the outward, non-individual forces of the material and social environment enables social life to be inscribed into the general dimension of history. In other words, the only forces able to transform our biological dimension are social ones, and they are more applicable to the body and its physiology than to psychics and its libidinal genealogy. So Freud can only be approved of if his treatment of psychics can be translated into the combination of two tendencies: the conservative-biological, and the progressive-sociological-the two tendencies that could construct a dialectics of societal development.

Voloshinov's argument in Freudianism is similar-it unfolds in favor of biology due to its fusibility with social infrastructure. He interprets psychoanalysis as an artificial transposition of biological issues into a psychic context. According to Voloshinov, in psychoanalysis the contents of classical subjective psychology was molded into the newly and artificially montaged terrain of psychics, sexuality, and the unconscious (1976: 67-75).

One of the principal rebukes by Voloshinov is that the unconscious is in fact conscious. He insists that the work of the unconscious is not as contingent or mechanical as Freud would claim it to be. On the contrary, it inherits many parameters of subjective psychology which identify psychics with consciousness, therefore Voloshinov disputes the necessity to derive separate realms for the functioning of desires and phantasmatic imaginaries (1976: 67-75). According to him, it would be more appropriate to allege that something unconscious acquires certain specific forms only on entering consciousness, that is, with the aim of temporary inner self-observation and introspection. In other words, we can interpret the unconscious as a force that acquires certain form and content only after going through conscious procedures, so that the unconscious can only be considered as one of the functions of consciousness and not the other way round-as in psychoanalysis-when consciousness is just the imaginariness of reality serving as just a material to unravel the unconscious. In his seminars on the "I," Lacan explicitly states that the system of consciousness didn't fit into Freud's theory (2009: 155-62). The "I" that is inscribed 


\section{Keti Chukhrov}

in being, in reality (social context) does not coincide with the "I" of the subject of the unconscious. The "I" of the social context is imaginary, illusionary, until it does not become the "I" of the unconscious. The unconscious is definitely intersubjective and dispersed, but nevertheless its analytical sphere is confined to the analysis of a subject.

It should also be remarked that the unconscious it is constructed by desire, and as Lacan many times explicitly claims in the seminars on the "I," desire has nothing to do with consciousness. Lacan actually emphasizes the fact that Freud treated consciousness either as a filter of reality, that is, as the instrument of its perception, or as the self-reflective Cartesian machine that failed to be efficient. In Psychoanalysis, the "I" is not cognized in a frame of consciousness. This is the conjecture that brings a specific consequence: namely, that it is the unconscious that is able to deal with intersubjectivity and objective realia, whereas consciousness is only for individual introspection that just remains imaginary. However, despite the broadened scope the unconscious acquires in psychoanalysis, in comparison with consciousness, the focus of analysis remains the Subject that is biased by desire. In other words, for Lacan it is exactly the consciousness that is limited and individual, whereas the unconscious is intersubjective and permeated with the clamor of reality, being in its own turn the repository of desire and the symbolic. In psychoanalysis, emancipation is either understood via the hegemony of the unconscious or dismissed altogether as the form of vitalism. In Soviet psychology and philosophy it was the other way round. Consciousness had nothing to do with introspection, it was the assemblage of the objectively-biased social phenomena. Objective reality is viable by the token of a human consciousness being part of its material dialectics. And last but not least, consciousness is the form of the voluntary demand for the general, for the objective. The subject is not studying itself but is constructing the objective.

In Freud's work on sexuality, both its social and physiological parameters are superceded by psychics and are thus deprived of physical, somatic and hence materialist impact, which would enable them to be more directly dependent on social and economic factors. The reduction of sexuality to a biological dimension would enable it to be redirected to the sphere of the genital and its innervations, which is actually antisexual and applies to sex just as to material necessity-without the troublesomeness of individual psychics and its traumatic bond with familial and personal biographies.

According to Voloshinov, Freud is not interested in any material functions of the somatic, but rather by its subjective impact on psychics; that is, he is trying to determine this impact from within psychics itself. What is important for him is the reflection of the somatic in the "soul," or psyche, no matter what these somatic phenomena might be beyond the psyche. Voloshinov dismisses Freud's theory of erogenous zones, since Freud does not provide any physiology of these zones or the functional 
work exercised by them; he is preoccupied only with the subjective psychic equivalents of these zones and their place in the psychoanalyticallydetermined libido. In Freudianism, Voloshinov writes:

Freud makes no provision for a physiological theory of the erogenous zones, he takes no stock whatever of the chemistry or their physiological relationship with other parts of the body. It is only their psychical equivalents that he subjects to analysis and investigation, that is, he focuses attention on the role played by subjective presentations and desires, associated with the erogenous zones, in the psychical life of a human individual and from that individual's inner, introspective point of view. [...] The internal secretion of the sex glands, its influence on the operation and form of other organs, its relationship with the constitution of the body,-all these processes, detectable in the external material world, are left completely undefined by Freud. How the role of an erogenous zone in the material composition of the body connects with the role it plays in the subjective psyche, taken in isolation, is a question for which Freud provides us no answer. As a result, we are presented with a kind of duplication of erogenous zones: What happens with erogenous zones in the psyche becomes something completely separate and independent of what happens with the psychically, chemically, and biologically in the material organism (Voloshinov 1976: 71).

Voloshinov is insisting here that the body and organism should not be inscribed complementarily into the realm of psychics and sexuality, so as to make the objective body endowed with the innermost and psychically complex of drives and imaginary associations, thus generating some sort of introspective imaginary of a body. Voloshinov is calling for the following: psychics should complement the objective body and be inscribed into the objective social surrounding. This premise is very important in understanding not only Andrey Platonov's anthropology, but more generally for interpreting the ethics of numerous cultural, artistic, and political phenomena of Soviet socialism with its mistrust of desire and pleasure.

Again, the debate against desire and enjoyment among representatives of Soviet psychology and philosophy-Voloshinov, Vygotsky, Leontiev, Ilyenkov-resided in the conjecture that along with subjective selfintrospection as the realm of desires, imaginaries, and emotions there is an objective dimension of human activity, conditioned by outward experience, and in it desire is not a prevailing component at all. The objective experience has to rely on completely different material components of behavior, which have very little to do with desires, emotions and imaginaries (phantasms). Desire in its own turn is engendered by libidinal economy, hence the privileged role of the unconscious that brings forth the dimension of the libidinal as a feature of capitalist production. But to 


\section{Keti Chukhrov}

repeat again: what is not envisioned in psychoanalysis is what happens if, by the token of the evacuation of libidinal economy, the function and the toil of desire expires.

So it is only in the light of subjective self-consciousness that the map of our psychic life seems to be the struggle and trouble of libidinally biased desires and imaginaries. Self-consciousness and self-introspection cannot be the source for objective motives of life and social or class struggle. Such an argument leads us as far as to assert the extreme dimension of the general, of the idea as the radicalness of the non-self. In this case it is not the impact of sexuality that influences the social or linguistic realm (as is the case with Lacan)-when the social infrastructure is permeated with the pleasure principle and libidinality-but the opposite: the general, the social consciousness, the idea, occupy the body-physiologically preserving functions of sex as a reflex, but unable to exercise sexuality. Then, communist society would be the society that would not need any Anti-Sexus device whatsoever. It would dispense with sexuality in favor of the dialectics between direct physical needs and social goals.

\section{IV}

When we place into doubt all kinds of liberalisms and their libertarian and permissive rhetoric; when we, consequently, claim that liberalism is no less embedded in ideology than any authoritarian society of historical socialism, we imply that by the same token (since liberalism is also an ideology) societies of historical communism might have been no less "liberal" despite their authoritarian infrastructure. ${ }^{4}$ If we follow such an argument, then liberalism would function as ideology, whereas idea and ideology, in their own turn, would be considered as something cracked and differentiated. We should not then be so intimidated by the symbolic dimension of the idea (and ideology), since it is also evolving in the regime of difference and deviation. But what I would endeavor to assume in reference to Platonov and Soviet cultural ethics would be the converse logic, which I shall now lay out.

It is not that sexuality can be extended into the zone of the social or the zone of the sublime, nonetheless preserving its libidinal character so that the ideal stays permeated by the "other paths" of libidinality, the argument discussed by Aaron Schuster in his explication of the libidinal

4 This logic is often applied in Slavoj Žižek's arguments mentioned in his numerous presentations. In his conversations he often mentions that the embodiments of disciplinary regimes-the Soviet army, or jail, for example, were organized as deviations, as corrupt forms of rule, whereas the permissiveness of liberal society might exert ideology. This leads to the assertion that ideology is biased by deviation and liberal permissiveness-by ideological rigidity. 
(2013: 41-47). ${ }^{5}$ On the contrary, the sublime, the delibidinized, invades material and immanent bodies and things, exerting the dimension of generality and idealness, which the body as a material object can not often endure. It is not that sexuality and the libidinal become dematerialized in ideology, but the idea gets materialized in a body. Death is therefore never tragic to Platonov, because the death of body is not experienced as the end. It is interesting that while in Western modernism there are so many metaphors of living corpses, of the dead who are bodily alive, in Soviet prose even when the body is on the verge of survival, the life and struggle still go on. This is because life resides in the idea of communism, rather than in the finite body. But such an idea is embodied in concrete human bodies. Hence, what is really tragic is the lack of communism by its nonimplementability in the finite life of finite people.

The claim against ideology and any hegemony of an idea is that it is actually the same as power and authority. But in the case of Platonov as well as many other cases from the Soviet socialist context, the idea cannot be identified with power, since power itself might happen to be a deviation from an idea. If we take Platonov's stories: Chevengur (1978), The Foundation Pit (2009), "Djan" (2008), or his novel Happy Moscow (2012) we see that sex is not banished or limited by any imperative in them. Sex as the material function of body is always present. Its difference from sexuality is just that it functions as a simple necessity, accessible despite an extremely poor life, where the imaginaries and phantasms of desire are substituted by the toil of "building" communism-without any surplus economy and its elements, that is, without the libidinality that would construct itself as sexuality.

There is an eloquent episode in Platonov's "The River Potudan" (2008: 225-47). Nikita, Ljuba's husband, has sexual intercourse with her for the first time after hesitating to do so for a long time. Platonov describes this moment as a "poor and inevitable pleasure, from which Nikita didn't acquire more joy than he hitherto experienced with Ljuba without it." (2008: 245). In another of Platonov's novels, Happy Moscow, the chief protagonist Moscow Chestnova says:

“I've just worked it out-why it is that people's lives together are so bad. It's bad because it's impossible to unite through love. I've tried so many times, but nothing ever comes of it-nothing but some kind of mere delight. You were with me just now-and what did you feel? Something astonishing? Something wonderful? Or nothing much?”

"Nothing much," agreed Semyon Sartorius.

5 In his comment to Platonov's “The Anti-Sexus,” Aaron Schuster emphasizes this feature-namely, the incongruence between genital sexuality and the libidinal drives as theorized in Freud's interpretation of the libido (2013). 


\section{Keti Chukhrov}

"My skin always feels cold afterward," pronounced Moscow. "Love cannot be communism. I've thought and thought and I've seen that it just can't. One probably should love-and I will love. But it's like eating food-it's just a necessity, it's not the main life."

Sartorius was hurt that his love, gathered during the course of a whole life, should perish unanswered the first time. But he understood Moscow's excruciating thought: that the very best of feelings lies in the cultivation of another human being, in sharing the burden and happiness of a second, unknown life, and that the love which comes with embraces brings only a childlike, blissful joy, and does nothing to solve the task of drawing people into the mystery of a mutual existence (Platonov 2012: 53).

This passage is reminiscent of Voloshinov's claims that self-consciousness can only be the reflection of class consciousness, since realizing oneself is only possible via the glance of another representative of one's class; any personal, linguistic or intimate reactions can only stem from objective roots (Voloshinov 1976: 17-29).

\section{V}

Returning to the issue of property in the context of sexuality we could emphasize that sexuality is much more dependent on the impact of property machines than it is constructed by traumatic or perverse undercurrents-this is the aspect that is somehow ignored in psychoanalysis. Following our assumption made above, sexuality can not be constituted without capitalist production and without surplus economy: it is but the consequence of the libidinality of desire and to its fusion with phantasmatic imaginaries. Sexuality and desire should have a backup, which has to be materially designed and embodied as the program of desire. The extremity of shortage economy which was the "normal" condition for socialism does not produce enough surplus in economy, in imaginaries, in commodity production and in production itself. The fact that a thing, an object, is produced via its use value evicts the phantasmatic parameters of things and bodies reducing the commodities to their crude utilitarian function, general necessity, removing from them the surplus of attractiveness. In such conditions the very form of commodity distribution has to de facto eliminate the possibility of libidinal desire and sexuality, since they are but a satellite of surplus economy. The question then would be whether the non-libidinal and non-capitalist economy would need a psychoanalytical lexicon at all.

If we look at the zones of poor life in the framework of a capitalist economy we can observe a condition, obscenely manifested in postsocialist economies of primitive accumulation. In them, the surplus element of 
an economy is either too innovative to automatically permeate social production, or not materially implementable whatsoever. If in the spheres of a non-profit socialist economy sexuality is constructed without a libidinal surplus, in the impoverished zones of the already capitalist, but still primitive, surplus economy the phantasm of libidinally biased enjoyment is already there, yet it can not be easily achieved because it is still too "expensive." This is because sex in conditions where it has not yet become the proper "language" of sexuality (sexuality understood as discourse in the Foucauldian sense) is often used as currency to pay for the future material embodiment of attractive phantasmatic images. In the conditions of an impoverished but already capitalist economy, sexuality as the realm of libidinal pleasure is still remote. But what would be achievable or accessible is the task of striving towards such pleasure-the quest to either acquire the attractiveness of the libidinally desired body, or to become such a body-that is impossible without the culture of consumption and commodification.

Interestingly, it is exactly in the conditions of a poor economy that the commodity items are at stake (as in Pasolini's movies Mamma Roma [1962], or Accattone [1961]). Sex for impoverished women (mostly in the mode of prostitution) is not yet embodying any desire or sexual pleasure at all. Desire is invested in the quest to acquire more property. The same could be said about the early post-Soviet social economic situation. Here the phantasmatic imaginary is prosperity and feminine attractiveness, exactly identified with the hunt for commodities. Such a mode of material life is already biased by a libidinal economy, but its "sexualization" has not yet taken place. The traumatic object of desire in it is not sexual pleasure and enjoyment, but an acquisition of the novel items of imaginary private property which can unleash a striving for the libidinal, but out of which a fully constructed sexuality has not yet emerged. This is why after the demise of authoritarian socialism one confronts so many examples of sexual abuse and victimization instead of feminist agencies and sexual freedom, because sexuality on such a transitory stage functions as a currency exchange rather than lust or the phantasm of liberation. To repeat once more, desire in such cases is conditioned by the quest for property accumulation and not sexual desire. Those who have only recently come out of the social context of use value are not yet able to properly exercise their libidinality.

As a comparison I would like to briefly refer to the plot of Nymphomaniac (2013) a recent film by Lars von Trier. Desire functions here as pure surplus, it has an absolutely phantasmatic character and is detached from physical necessity. This is the reason why it can not saturate physical need even in the smallest degree. Yet it is this phantasmatically projected attractiveness of sexuality that gears desire, whilst simultaneously not being able to saturate it. Such phantasm, such desire, is of course completely detached from social context. However, it is precisely in 


\section{Keti Chukhrov}

a society biased by consumption and commodity fetishism that we will not witness any articulate existential demand for a commodity or reference to it in everyday life. This is because in the conditions of a developed libidinal economy, when there is no social experience of scarcity, a commodity stops being an existential necessity. A commodity is then not a basic need, but rather a variation of phantasmatic desire. Consequently, the more there is freedom of consumption the more the surplus form of an economy is concealed; what comes to the foreground are mainly phantasmatic imaginaries, not directly referring to the commodity-oriented character of life and production. The protagonist of Von Trier's Nymphomaniac would not even question what stylistic, economic, monetary or physiological parameters construct the image of her sexuality and the phantasmatic stages of her libidinal striving-namely, she would not question what the surplus value is that makes all those parameters attractive? The issue here is not the prosperity of a concrete individual, namely of the protagonist, but a simple formula: if one has to think about survival, sexuality functions as a simple de-libidinized necessity rather than any imaginary about sexual pleasure.

\section{Bibliography}

Peshkov, V. Makhlin, ed. (2000). Bakhtin pod Maskoy [Bakhtin behind the mask]. Moscow: Labyrinth.

Ilyenkov, Evald (1991). "Dialectica abstractnogo i concretnogo" [Dialictics of the Abstract and the Concrete]. In Filosophia I Kultura, 276-94. Moscow: Izdatelstvo Politicheskoy Literatury.

Mamardashvili, Merab (1972). "Analysis of Consciousness in Works by Marx" [Analis soznaniya $\mathrm{v}$ rabotakh Marxa]. http://www.mamardashvili.com/files/pdf/ form/07\%20Анализ\%20сознания\%20в\%20работах\%20Маркса.pdf.

Mikhailov, Boris (2007). Suzi et Cetera. Cologne: Walther Koenig.

Lacan. Jacque (2009). “Ja v teorii Freuda i v technike psychoanalysa” [The Ego in Freud's Theory and in the Technique of Psychoanalysis]. In Seminars, Vol. 2, 155-62. Moscow: Gnosis.

Platonov, Andrey (2013). “The Anti-Sexus.” Trans. Anne. O. Fisher. Cabinet 51: 48-53.

Platonov, Andrey (1988) "No odna dusha u cheloveka” [But a Man Has One Soul] [1924]. In Gosudartvenny Zitel [State Resident], 312-20. Moscow: Sovetsky Pisatel.

Platonov, Andrey (2012) Happy Moscow. Trans. Robert and Elizabeth Chandler. New York: New York Review Books Classics

Platonov, Andrey (2008) "The River Potudan." In Soul: And Other Stories. Trans. Robert and Elizabeth Chandler and Angela Livingstone, 225-47. New York: New York Review Books Classics.

Schuster, Aaron (2013). "Sex and Antisex." Cabinet 51: 41-47. 
Voloshinov, Valentin (1976). Freudianism: A Marxist Critique. Ed. I. R. Titunik and Neal H. Bruss, trans. I. R. Titunik. New York: Academic Press.

Vygotsky, Lev and Alexander Luria (1990). "Foreword to Freud's 'Beyond Pleasure Principle’” [1925]. In Freud, Sigmond. Psikhologia bessoznatel'nogo [Psychology of the Unconscious] 29-37. Moscow: Prosveshenie. 